\title{
Initiation, Development, and Survival of Cleistothecia of Podosphaera aphanis and Their Role in the Epidemiology of Strawberry Powdery Mildew
}

\author{
David M. Gadoury, Belachew Asalf, M. Catherine Heidenreich, M. L. Herrero, M. J. Welser, \\ Robert C. Seem, Anne Marte Tronsmo, and Arne Stensvand
}

First, third, fifth, and sixth authors: Department of Plant Pathology and Plant-Microbe Biology, Cornell University, New York State Agricultural Experiment Station, Geneva, NY 14456; second and seventh authors: Norwegian University of Life Sciences, Department of Plant and Environmental Sciences, 1432 Ås, Norway; fourth and eighth authors: Norwegian Institute for Agricultural and Environmental Research, Plant Health and Plant Protection Division, 1432 Ås, Norway. Accepted for publication 20 November 2009.

\section{ABSTRACT}

Gadoury, D. M., Asalf, B., Heidenreich, M. C., Herrero, M. L., Welser, M. J., Seem, R. C., Tronsmo, A. M., and Stensvand, A. 2010. Initiation, development, and survival of cleistothecia of Podosphaera aphanis and their role in the epidemiology of strawberry powdery mildew. Phytopathology 100:246-251.

A collection of four clonal isolates of Podosphaera aphanis was heterothallic and was composed of two mutually exclusive mating types. Cleistothecial initials $\approx 20$ to $30 \mu \mathrm{m}$ in diameter were observed within 7 to 14 days after pairing of compatible isolates and developed into morphologically mature ascocarps within 4 weeks after initiation on both potted plants maintained in isolation and in field plantings in New York State and southern Norway. Ascospores progressed through a lengthy maturation process over winter, during which (i) the conspicuous epiplasm of the ascus was absorbed; (ii) the osmotic potential of the ascospore cytoplasm increased, resulting in bursting of prematurely freed spores in water; and, finally, (iii) resulting in the development of physiologically mature, germinable, and infectious ascospores. Release of overwintered ascospores from field collections was coincident with renewed plant growth in spring. Overwintered cleistothecia readily dehisced when wetted and released ascospores onto glass slides, detached strawberry leaves, and leaves of potted plants. Plant material exposed to discharged ascospores developed macroscopically visible mildew colonies within 7 to 10 days while noninoculated controls remained mildew free. Scanning electron and light microscopy revealed that cleistothecia of $P$. aphanis were enmeshed within a dense mat of hyphae on the persistent leaves of fieldgrown strawberry plants and were highly resistant to removal by rain while these leaves remained alive. In contrast, morphologically mature cleistothecia on leaves of nine deciduous perennial plant species were readily detached by simulated rain and seemed adapted for passive dispersal by rain to other substrates. Contrary to many previous reports, cleistothecia appear to be a functional source of primary inoculum for strawberry powdery mildew. Furthermore, they differ substantially from cleistothecia of powdery mildews of many deciduous perennial plants in their propensity to remain attached to the persistent leaves of their host during the intercrop period.

Additional keywords: Sphaerotheca macularis.
Numerous studies of strawberry powdery mildew have examined the means of overwinter or intercrop survival of the causal organism, Podosphaera aphanis (syn. Sphaerotheca macularis), including survival on alternate hosts, hibernation as mycelium in dormant infected strawberry (Fragaria $\times$ ananassa) crowns, and survival on the persistent green leaves of strawberry plants in the field $(9,15,17)$. There is general agreement among several authors that the pathogen can survive winter as mycelium on green persistent leaves $(9,15,17)$. Colonies on these tissues supposedly resporulate in spring and, thereby, perpetuate the disease.

Like most powdery mildews, $P$. aphanis also produces cleistothecia. Salmon (18) noted that, although powdery mildew on strawberry was common in England in 1900, he was not able to find cleistothecia there, although he had received cleistothecia of the pathogen collected in Geneva, NY by J. C. Arthur, (1) to use as reference material in his search for the sexual stage. Cleistothecia were not reported in England until 1960 by Khan (14). As late as 1962, Jhooty and McKeen (11) deemed the

Corresponding author: D. M. Gadoury; E-mail address: dmg4@ cornell.edu

* The $e$-Xtra logo stands for "electronic extra" and indicates that Figures 1 and 3 appear in color online.

doi:10.1094/PHYTO-100-3-0246

(c) 2010 The American Phytopathological Society discovery of cleistothecia in Canada to be sufficiently novel to merit publication as a first report from North America, although they were obviously unaware that Salmon (18) had earlier received cleistothecia collected in New York (1). Giles (9) reported on the production of cleistothecia in France but was not able to reproduce the disease from ascosporic inoculum. Similarly, Howard and Albregts (10) reported on the presence of cleistothecia of $P$. aphanis in Florida in 1982. In the second edition of the APS Compendium of Strawberry Diseases (15), it is stated that "Cleistothecia, when produced, do not appear to function as perennation bodies." Peries (17) reported that there was no evidence that the pathogen was heterothallic, and that failed inoculation experiments were evidence that cleistothecia played no essential part in the life history of the fungus. Kaluzhny and Zibtsev (13) reported that cleistothecia were common in Ukraine, and that viable ascocarps were recovered in spring from overwintered green leaves but not from soil. Thus, formation of cleistothecia seems at the same time both widespread and exceptional, and is commonly deemed to be irrelevant to perpetuation of the disease.

We have recently demonstrated that cleistothecia of $P$. aphanis are, indeed, functional survival structures; that the pathogen is heterothallic; and that it produces germinable, infectious ascospores in synchrony with host regrowth in spring. Furthermore, in contrast to cleistothecia of several deciduous perennials, the 
ascocarps exhibited an unusually tenacious attachment to foliar mildew colonies that results in their retention on persistent green leaves over winter. Preliminary accounts of our findings have been published elsewhere $(7,8,19)$.

\section{MATERIALS AND METHODS}

Production and maintenance of clonal isolates and crossing of isolates. Strawberry leaves bearing young, sporulating colonies of $P$. aphanis were obtained from colonized strawberry leaves in plantings at Hamar, Ringsaker, Larvik, and Sola, Norway. After collection, leaves were placed in petri dishes to allow resporulation. To obtain clonal isolates, single conidial chains were transferred from the above leaves to mildew-free leaves in petri dishes as described by Pearson and Gadoury (16). Colonies that developed were subcultured in the same manner onto mildew-free leaves to ensure that clonal isolates were obtained. Once reduced to clonal lines, the isolates were maintained on surface-sterilized (5\% sodium hypocholorite plus $0.05 \%$ Tween 20 , followed by three sterile distilled water rinses) detached strawberry leaves on water agar. Four clonal lines were obtained. Isolates were transferred as necessary to new leaflets as conidial chains using a human hair affixed to a Pasteur pipette as described by Gadoury and Pearson (6). Isolates to be crossed were placed on opposite sides of the midvein of a leaflet and the leaflets were incubated at 13 to $15^{\circ} \mathrm{C}$ with $12 \mathrm{~h}$ of light. Establishment of each isolate transferred was confirmed 4 to 6 days after inoculation before results were taken on the outcome of each pairing 14 to 28 days after inoculation. The isolates were crossed in all possible combinations, with each pairing replicated three times on separate disease-free leaflets maintained on water agar, and the experiment was repeated twice. Pairings were scored as compatible if one or more replicates in both runs of the experiment produced mature cleistothecia with the full complement of ascospores.

Scanning electron and light microscopy studies of initiation and development of ascocarps. Leaves bearing cleistothecia in various stages of development were collected from research plantings of cv. Earliglow in 2007 and 2008 at the New York State Agricultural Experiment Station (NYSAES) in Geneva, NY. Several disks $\approx 2 \mathrm{~mm}$ in diameter bearing mildew colonies supporting developing ascocarps were cut from the leaves. Disks intended for scanning electron microscopy were immediately fixed in $4 \%$ glutaradlehyde buffered with $0.05 \mathrm{M} \mathrm{KPO}_{4}$ at $\mathrm{pH} 6.5$ for $2 \mathrm{~h}$. The samples were rinsed six times in $0.05 \mathrm{M} \mathrm{KPO}_{4}$ at 10 -min intervals, rinsed twice in distilled water, and subsequently postfixed in $\mathrm{OsO}_{4}$ for 1.5 to $2 \mathrm{~h}$. The leaf pieces were then rinsed in distilled water six times at 10-min intervals, dehydrated in a seven-step acetone series, critical point dried, mounted, and sputter coated with gold before examination and photography. Disks intended for sectioning and viewing under light microscopy were immediately fixed in formalin/acetic acid/alcohol (12), dehydrated in a tertiary butyl alcohol series, infiltrated with paraffin, and serially sectioned at 10 to $15 \mu \mathrm{m}$. The sections were adhered to glass microscope slides, dewaxed in Histoclear, and subsequently stained with $1 \%$ safranin $\mathrm{O}$ in $50 \%$ ethanol followed by counterstaining in $0.1 \%$ fast green in clove oil as described by Johansen (12). Developmental studies were repeated on cv. Elan in 2008.

Maturation of ascocarps, ascospore discharge, ascospore germination, and infection of strawberry leaves. Detached mildewed leaves bearing cleistothecia were collected in October 2005, 2007, and 2008; encased in envelopes made from fiberglass window screen; and stored overwinter on the ground at NYSAES. In each seasonal repetition of the experiment, at monthly intervals from January to March and at 2-week intervals thereafter, 2-cm disks bearing at least 20 to 50 ascocarps were cut from the leaves, attached to a 9-cm disk of filter paper wetted with distilled water, and suspended above mildew-free strawberry seedlings in 2006 (cv. Elan) or above detached leaves in 2008 and 2009 (cv.
Earliglow) for $24 \mathrm{~h}$ at 20 to $22^{\circ} \mathrm{C}$. During these experiments, the Elan seedlings were enclosed within clear polycarbonate drinking cups covered with a double layer of tissue to exclude conidia of $P$. aphanis. Detached leaves of Earliglow were enclosed in 9-cm polystyrene petri dishes. Treatments were replicated 10 times in 2006 and 5 times in 2008 and 2009. All tissues were incubated at 20 to $22^{\circ} \mathrm{C}$ for 14 days after exposure to cleistothecia and were then examined at $\times 20$ magnification for the presence of mildew colonies. An equal number of disks were placed on wet filter paper in the lid of a petri dish and suspended above a glass microscope slide within the dish for $24 \mathrm{~h}$ at 20 to $22^{\circ} \mathrm{C}$ in each year of the study. Detached leaves of 'Korona' were also inoculated on 20 May 2007 ( $\approx 2$ weeks before bloom) as above using cleistothecia borne on leaves overwintered at Egge, Norway.

The water potential of ascospore cytoplasm was determined as previously described (5) by mounting 10 arbitrarily selected ascocarps on glass microscope slides in distilled water or $0.2,0.4$, $0.6,0.8$, and $1.0 \mathrm{M} \mathrm{NaCl}$ at monthly intervals from October 2007 to May 2008 and from October 2008 until May 2009 at NYSAES. The water potentials generated by the $\mathrm{NaCl}$ solutions were 0 , $-670,-1,262,-1,838,-2,411$, and $-2,990 \mathrm{KPa}$ (20). The ascocarps were crushed on the slides and observed under phase contrast illumination. The molarity at which incipient plasmolysis (2) was observed in the freed ascospores was recorded. The percentage of cleistothecia that contained viable ascospores was assessed by mounting 20 to 25 arbitrarily selected ascocarps from each collection date on glass microscope slides (five ascocarps per slide) in a $0.5 \%$ (wt/vol) aqueous solution of fluorescein diacetate (FDA). The cleistothecia were fractured under a cover glass, allowed to absorb the stain for $5 \mathrm{~min}$, and then observed under bright-field microscopy at $\times 200$ and immediately afterward under fluorescence microscopy (325- to 500-nm excitation filter and transmission filter $>530 \mathrm{~nm}$ ) at $\times 200$ magnification. The percentage of cleistothecia containing viable (fluorescing) spores was estimated based upon comparison of the bright-field and fluorescence views. The total number of ascospores per ascus was also recorded for each ascocarp containing viable spores, and the presence or absence of fluorescent epiplasm in the ascus was noted. Parallel assessments of ascocarp and ascospore development and viability using FDA were made as above at approximately monthly intervals, beginning in fall 2007 and 2008, and continuing until June of the following years, at Ås, Norway, utilizing cleistothecia borne on Korona leaves.

Comparative studies of ascocarp retention and removal from leaves. Leaves bearing powdery mildew colonies with abundant cleistothecia were collected in September 2007 in Geneva, NY from strawberry plants (Fragaria $\times$ ananassa with $P$. aphanis) and nine woody deciduous perennial hosts: grapevine (Vitis vinifera with Erysiphe necator, syn. Uncinula necator), English hawthorne (Crataegus laevigata with $P$. clandestina), white ash (Fraxinus americana with Phyllactinia guttata), Norway maple (Acer platanoides with E. circinata, syn. U. circinata), American hazelnut (Corylus americana with E. alni, syn. Microsphaera alni), sycamore (Platanus occidentalis with E. penicillata, syn. M. penicillata), chestnut oak (Quercus prinus with E. extensa, syn. M. extensa), lilac (Syringa vulgaris with E. syringaejaponica, syn. M. penicillata), and sweet cherry (Prunus avium with Podosphaera clandestina). The experiment was repeated in Norway in October 2007, when leaves were collected as above from strawberry, ash ( $F$. excelsior with Phyllactinia guttata), oak ( $Q$. robur with $E$. alphitiodes), and lilac ( $S$. vulgaris with $E$. syringae-japonica).

The potential for cleistothecia to be removed from the above leaves and thereafter dispersed by rain events was assessed using a technique modified from Gadoury and Pearson (4). Three leaves bearing abundant cleistothecia were selected for each of the above host species, and a 1-cm disk was cut from each leaf. The disks were examined under a dissecting microscope at $\times 25$ magni- 
fication, the number of cleistothecia on each disk was recorded, the disks were shaken in an Erlenmeyer flask in distilled water for $1 \mathrm{~min}$, and the number of cleistothecia remaining on each disk was again determined at $\times 25$ magnification. The percentage of cleistothecia removed from each disk by agitation in water was calculated and recorded.

\section{RESULTS}

Crossing of isolates. Results of isolate pairings indicated the presence of two mutually exclusive mating types, with isolates

TABLE 1. Ascocarp formation in pairings of four clonal isolates of Podosphaera aphanis

\begin{tabular}{lcccc}
\hline Isolate pairing $^{\mathrm{a}}$ & Hamar & Ringsaker & Larvik & Soal \\
\hline Sola & + & + & - & - \\
Larvik & + & + & - & $\ldots$ \\
Kise & - & - & $\ldots$ & $\ldots$ \\
Hamar & - & $\ldots$ & $\ldots$ & $\ldots$
\end{tabular}

a Isolates were scored as compatible (+) when cleistothecia formed in one or more of three replicate pairings on detached strawberry leaves in both of two repetitions of the experiment.
Sola and Larvik representing a group that was self incompatible but which was readily compatible with a second self-incompatible group consisting of the isolates Hamar and Ringsaker (Table 1). No isolate grown by itself as an aseptic culture or paired with itself produced cleistothecia.

Initiation and development of ascocarps. Cleistothecia were found on mildewed strawberry leaves of nonsprayed research plots of cvs. Earliglow and Elan at NYSAES in mid-July 2007 and 2008 , respectively, $\approx 3$ weeks after harvesting of the first mature berries. Ascocarp initials $\approx 20 \mu \mathrm{m}$ in diameter were associated with dense colonies of pannose mycelium (Fig. 1A). In controlled pairing of isolates, ascocarps reached this state of development within 7 days after inoculation at $13^{\circ} \mathrm{C}$. Hyphae similar to anchorage hyphae described for E. necator (4) also developed as outgrowths of cells of the outer ascocarp wall once the ascocarp had reached $\approx 20 \mu \mathrm{m}$ in diameter (Fig. 1A). These hyphae grew down into and became intertwined with hyphae in the mildew colony (Fig. 1B). However, unlike E. necator, development of anchorage hyphae in Podosphaera aphanis was not followed by formation of morphologically distinct and more robust appendages. With the exception of their physical connection to the ascocarp, the hyphal outgrowths from the ascocarp wall were indistinguishable from the hyphae of the mildew

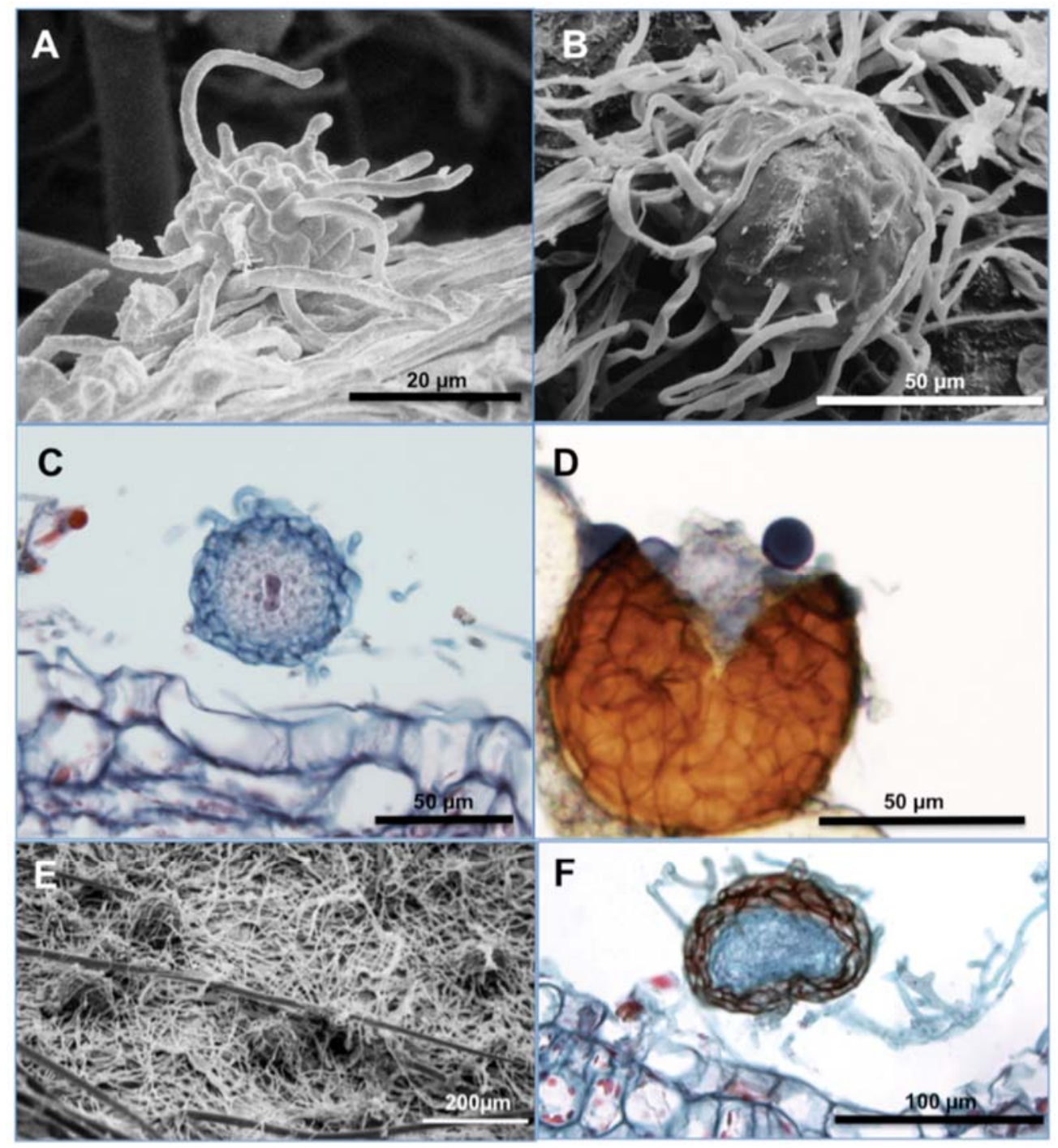

Fig. 1. Stages in the development of cleistothecia of Podosphaera aphanis. A, Ascocarp initial with early hyphal outgrowths from ascocarp wall and B, ascocarp at "yellow sphere" stage, $\approx 10$ days after initiation. Hyphal outgrowths have now become intertwined in the pannose mycelium of the mildew colony. $\mathbf{C}$, Cross section of ascocarp at $\approx 14$ days after initiation showing uninucleate ascus mother cell and binucleate ascus initial; D, crush mount of 4-week-old ascocarp mounted in Sudan Black B showing dark staining of lipid droplets; E, mature cleistothecia in pannose mycelium on persistent green leaf collected in September 2008; and F, mature ascocarp in cross section showing basal concavity and persistent pannose mycelium on leaf collected in September 2008. 
colony, although we did not observe anastomoses or formation of appressoria in the anchorage hyphae.

By the time the ascocarp had reached a diameter of $\approx 50 \mu \mathrm{m}$, differentiation of the centrum had begun to yield ascogenous cells (Fig. 1C) and cells of the outer ascocarp wall had transitioned from hyaline to yellow due to the accumulation of a yellow lipid compound, similar to that reported for E. necator (4) in that it was also darkly stained by Sudan Black B (Fig. 1D). Simultaneous to the intertwining of the anchorage hyphae in the mildew colony, the ascocarp also became enmeshed within the mildew colony by overgrowth of the pannose mycelium (Fig. 1E). A single ascus containing eight uninucleate ascospores was evident in ascocarps that reached $90 \mu \mathrm{m}$ in diameter, at which time the ascocarp wall was composed of thick-walled dark cells that appeared slightly flattened (Fig. 1F). Although generally spherical as they developed, cleistothecia were concavo-convex once they reached morphological maturity (Fig. 1F), $\approx 4$ weeks after initiation. Hyphal outgrowths from the ascocarp wall remained procumbent upon the surface of the mildew colony (Fig. 1E).

Maturation of ascocarps, ascospore discharge, ascospore germination, and infection of strawberry leaves. In each year of the study at NYSAES and in Norway, the modal number of ascospores per ascus decreased from eight ascospores per ascus in October to six ascospores per ascus at the time of initial dehiscence of cleistothecia. Epiplasm surrounding the ascospores appeared to be reabsorbed during overwintering, as were the lipid droplets that were originally conspicuous in ascus and ascospore cytoplasm in the autumn. In assessments at NYSAES, water potential of the ascospore cytoplasm also decreased during overwintering, resulting in increased turgor pressure in wetted ascocarps that reached a maximum immediately before the period of ascospore release (Fig. 2). The minimum molarity of $\mathrm{NaCl}$ that resulted in plasmolysis of $50 \%$ or more of the ascospores was $0.2 \mathrm{M}$ in October, 0.2 to $0.4 \mathrm{M}$ between November and February, 0.4 to $0.6 \mathrm{M}$ in March, and 0.6 to $0.8 \mathrm{M}$ in April and May of each year of the study. Ascocarp dehiscence was circumscissile, and the ascus remained attached by its base to the basal half of the ascocarp. When no longer under restriction by the intact ascocarp wall, the ascus swelled rapidly and, thereby, forced the two halves of the ascocarp apart, with the halves most commonly remaining attached at approximately one-quarter of their circumference, the point of attachment functioning as a hinge. Rupture of the ascus and forcible ascospore release generally occurred within $5 \mathrm{~min}$ of dehiscence at 22 to $25^{\circ} \mathrm{C}$ (i.e., room temperature) so long as the ascocarp remained in contact with a film of water. Once ascospore release had taken place, the ascocarps closed and, at $\times 20$ magnification, often could not be distinguished from intact and nondehiscent cleistothecia on the same leaf.

At NYSAES, ascospores were observed on glass slides but not enumerated in discharge tests performed on 23 March, 4 April, 19 April, and 25 April 2006. Colonies of P. aphanis developed following incubation on 30 and $50 \%$ of Elan seedlings exposed to wetted cleistothecia on 4 and 19 April 2006, respectively. Ascospores were enumerated following discharge tests performed in 2008 (Fig. 2A) and 2009 (Fig. 2B). Ascospore discharge occurred between 6 March and 28 May 2008 and between 10 March and 28 April 2009 (Fig. 2). In both years, the peak of ascospore release was in mid-April. Colonies of $P$. aphanis developed following incubation of 40 and $60 \%$ of detached Earliglow leaves exposed to wetted cleistothecia on 20 March and 18 April 2008, respectively; and following incubation of $20 \%$ of the detached Earliglow leaves exposed to wetted cleistothecia on 10 April 2009 (Fig. 3A). Noninoculated control seedlings (2006) and detached leaves (2008 and 2009) remained free of powdery mildew. The percentage of discharged ascospores that germinated on glass slides was 57 to $98 \%$ in 2008 and $42 \%$ to $89 \%$ in 2009 . The percentage of cleistothecia containing ascospores that reacted positively to FDA in viability assessments was 88 to $100 \%$ in
October 2005, 2007, and 2008, and remained $>80 \%$ in each year of the study, falling below 50\% in 2008 and 2009 only after the peak of ascospore release was observed (Fig. 2). Similar results were obtained in Norway, where the percentage of cleistothecia containing ascospores that reacted positively to FDA exceeded $80 \%$ in each monthly assessment between October and May of each year of the study. In Norway, colonies of $P$. aphanis developed following incubation of 5 of 18 detached Korona leaves exposed to wetted cleistothecia on 20 May 2007 (Fig. 3B). Noninoculated control leaves remained free of powdery mildew.

Comparative studies of ascocarp retention and removal from leaves. Cleistothecia of $P$. aphanis on strawberry leaves were unusually tenacious in their attachment to the mildew colony and resisted removal in laboratory tests (Fig. 4). In comparison, cleistothecia associated with powdery mildews of several woody deciduous perennials-oak, lilac, ash, grapevine, hawthorne, maple, filbert sycamore, and cherry in New York (Fig. 4A) and oak, lilac, and ash in Norway (Fig. 4B)-were readily removed by rinsing in water. Between 60 and $100 \%$ of all mature ascocarps on leaves rinsed in water were removed from the foregoing deciduous perennials whereas $>80 \%$ of the cleistothecia on the persistent leaves of strawberry were retained on the leaves after rinsing (Fig. 4).
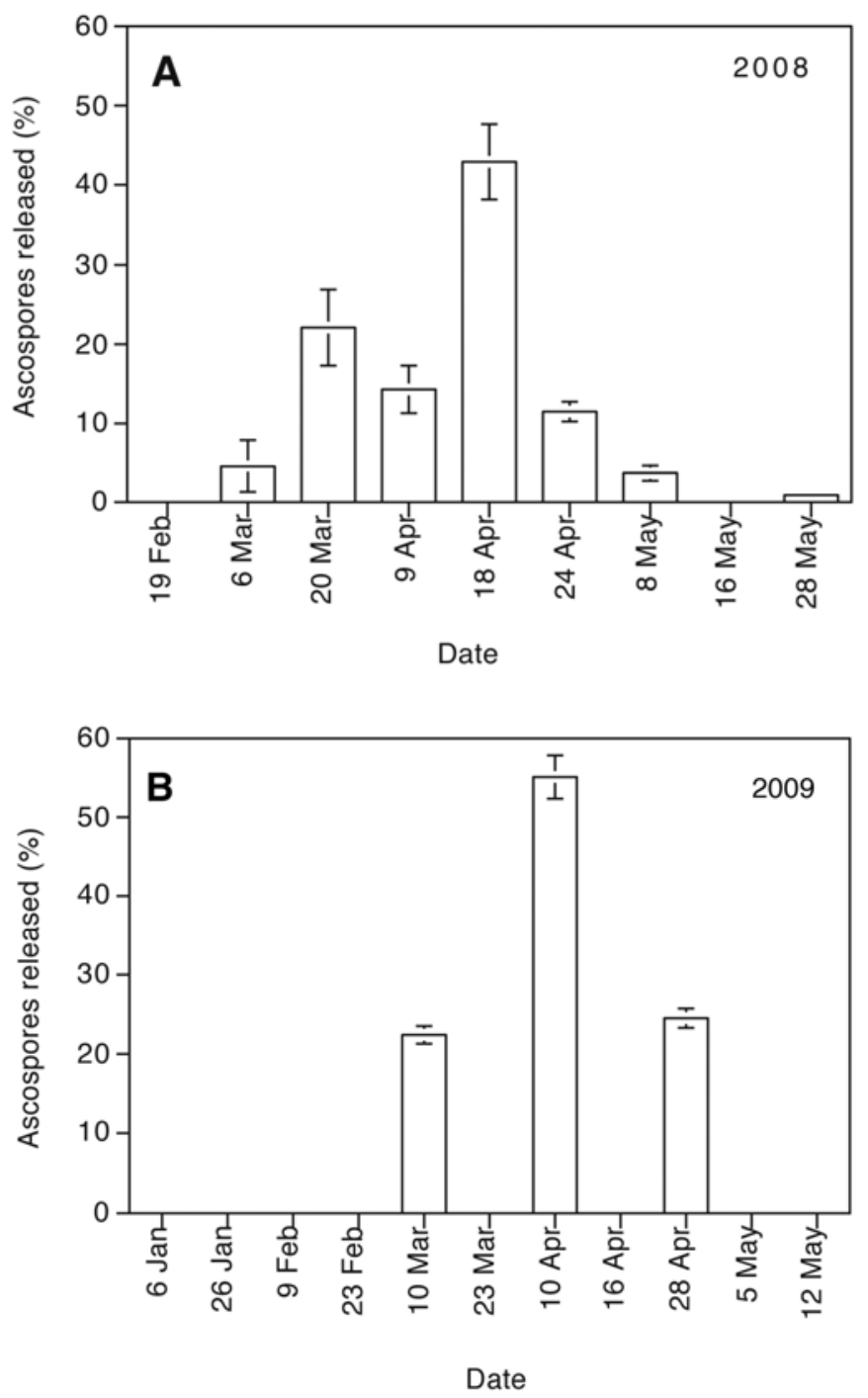

Fig. 2. Seasonal distribution of ascospore release by cleistothecia of Podosphaera aphanis at Geneva, NY in A, 2008 and B, 2009. Replicate leaf pieces bearing $\approx 20$ to 50 ascocarps were suspended in petri plates over glass microscope slides for $24 \mathrm{~h}$ at 20 to $22^{\circ} \mathrm{C}$, and the discharged spores were then enumerated. Bars represent one standard error of treatment means. 


\section{DISCUSSION}

Cleistothecia of $P$. aphanis followed an orderly process of initiation, development, and maturation that culminated with discharge of germinable and infectious ascospores. Viable ascospores were present within cleistothecia within 4 weeks after the ascocarps were initiated. There was a lengthy period of overwinter maturation during which an abundant lipid similar to that described for E. necator (5) was reabsorbed coincident with a decrease in the osmotic potential of the ascus and ascospore cytoplasm. The foregoing indicates that, as in E. necator, ascospore release in $P$. aphanis requires the presence of a film of free water on the ascocarp wall and the driving force for ascospore discharge is a consequent increase in turgor pressure within wetted ascocarps. The lengthy period of ascocarp maturation under field conditions resulted in a delay of ascospore release until the host resumed growth in late winter and early spring in each year of the study. The lack of ascospore release from newly formed and physiologically immature cleistothecia, the inability of ascospores to germinate when forcibly removed from intact ascocarps in autumn, and their tendency to burst in water when prematurely released may have contributed to their reputation as degenerate structures $(9,15,17)$. However, when collected in early spring during the peak period of ascospore release and placed over ontogenically susceptible leaf tissue, cleistothecia naturally released ascospores that gave rise to typical mildew colonies. Therefore, our results indicate that cleistothecia can be regarded as a functional form of primary inoculum in regions where they form and are provided with sufficient water to promote ascospore discharge.

Dispersal of physiologically mature cleistothecia to secondary substrates (e.g., bark) on deciduous perennial plants may

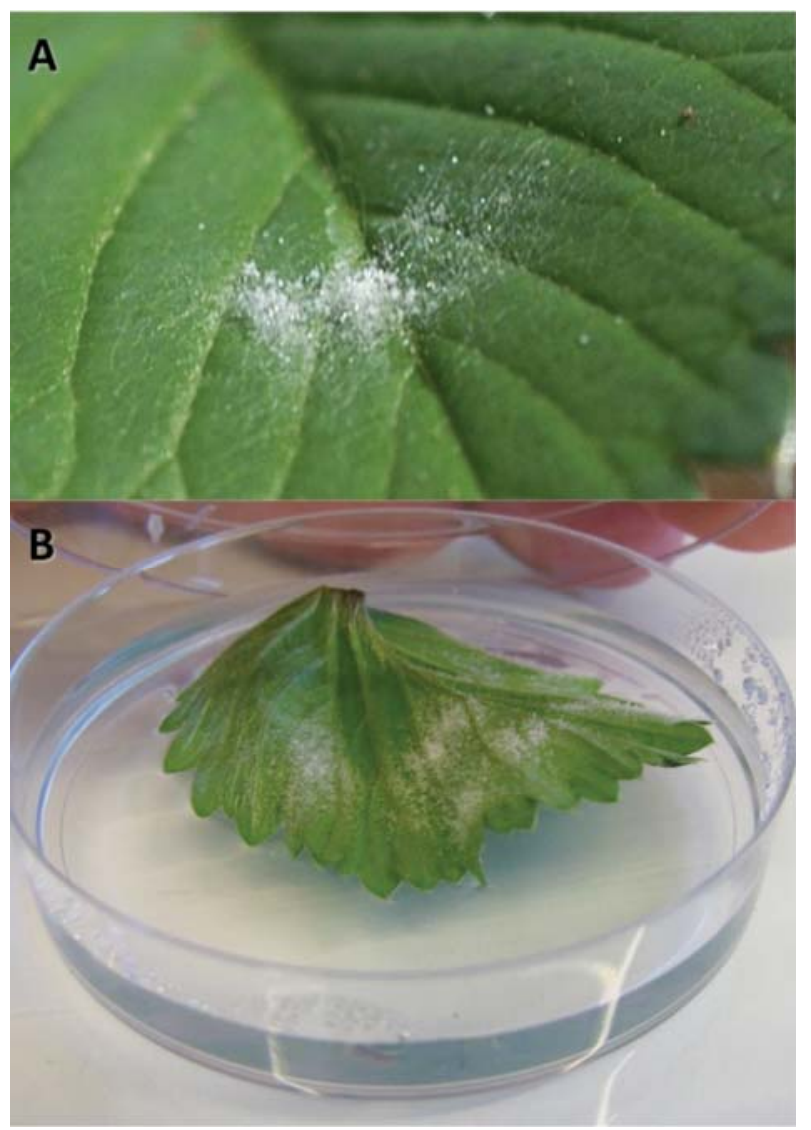

Fig. 3. Infection of detached strawberry leaves by ascospores discharged from overwintered cleistothecia suspended over leaves for $24 \mathrm{~h}$. Colonies: A, 12-day-old colony on 'Earlyglow' leaflet and B, 14-day-old colonies on 'Korona' leaflet. represent a means by which the primary inoculum is conserved and escapes burial consumption by detritivores (4). In a survey of nine such deciduous perennials, we found that cleistothecia of the relevant powdery mildew pathogens were easily removed by water and, therefore, would be subject to redistribution in rain events. In contrast, the cleistothecia of $P$. aphanis were tenacious in their attachment to the nondeciduous and persistent green leaves of strawberry and were retained on green leaves during winter. This tenacious attachment may be related to the interweaving and persistence of the pannose mycelium of the colony with the myceloid outgrowth from the ascocarp wall. Unlike the anchorage hyphae (4) observed in E. necator, the myceloid outgrowths of the ascocarp wall in $P$. aphanis maintain a physical connection to the ascocarps after it has matured, and appear to form a more persistent, if not permanent, attachment to the mildew colony. Whether this represents an adaptive mode for conservation of inoculum for powdery mildews of nondeciduous plants will require further research. However, in the case of $P$. aphanis on strawberry, the end result is that the cleistothecia are retained near the infection court (new leaves that emerge from the crown in spring) by virtue of their tenacious attachment to persistent overwintered leaves. Blumer (3) reported the tenacious attachment of cleistothecia to the host as a characteristic of Podosphaera sect. Sphaerotheca and Golvinomyces (syn. Erysiphe p.p.) spp. However, among several species within the above-mentioned genera, cleistothecia were easily rinsed from leaves once the ascocarps had matured, and tenacious attachment of matured ascocarps was noted only in P. aphanis on strawberry.
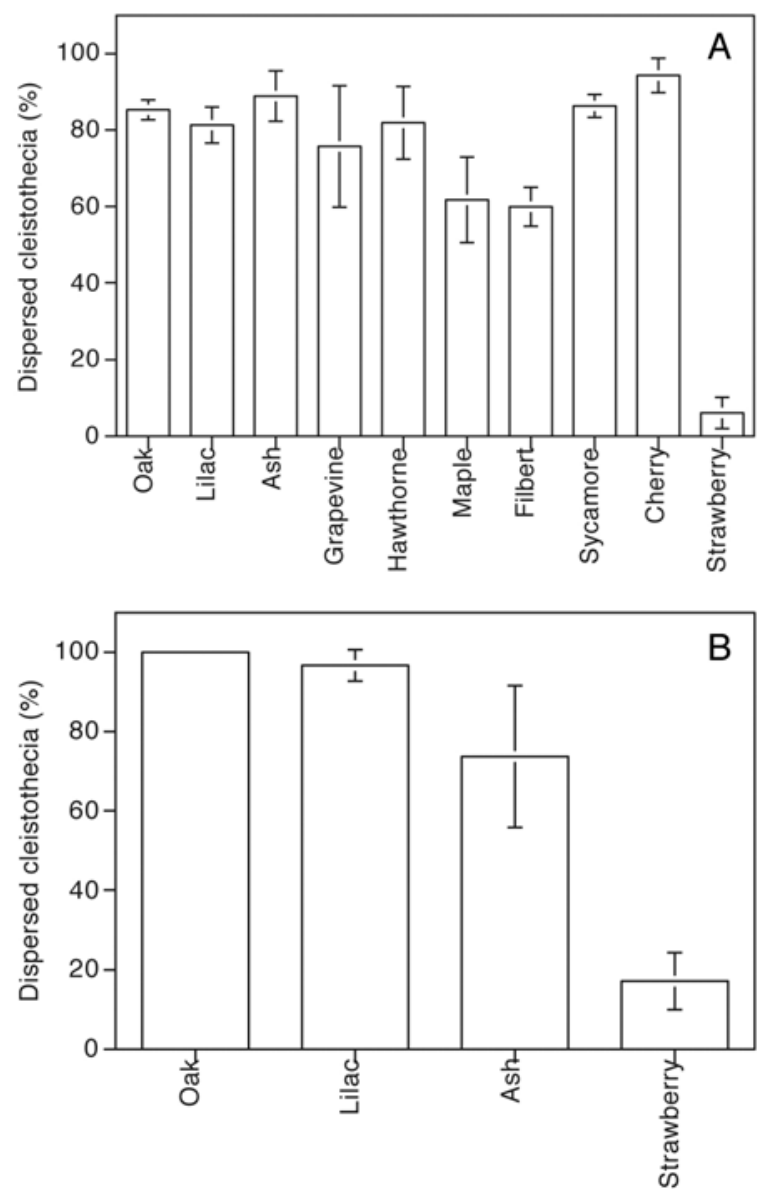

Fig. 4. Retention of cleistothecia on leaves of strawberry and nine deciduous perennial plants at A, Geneva, NY and B, Ås, Norway. Leaves were collected in autumn and density of ascocarps per unit of leaf area was determined microscopically before and after rinsing the leaves in water for $1 \mathrm{~min}$. Bars represent one standard error of treatment means. 
The heterothallic nature of the pathogen may provide one explanation for the geographically discontinuous and temporally irregular distribution of ascocarp formation $(1,8,10,11,13,19)$ (i.e., only one mating type may be present at a particular location or within a specific region). The existence of heterothallism also introduces certain considerations for scouting if cleistothecia are to be effectively detected in surveys. Gadoury and Pearson (4) illustrated the relationship between the timing of first appearance of ascocarps of E. necator under field conditions and the incidence and severity of foliar powdery mildew on grapevine. Consequently, disease must increase to a level or exist for a sufficient period of time so that the chance pairing of compatible mating types on the same tissue becomes possible and, thereafter, cleistothecia must increase to a level where their detection becomes feasible with the assessment methods employed. The low number of reports of the detection of cleistothecia does not necessarily prove that they are absent and may reflect a bias related to their presumed lack of importance in the epidemiology of strawberry powdery mildew. In both New York State and southern Norway, cleistothecia were abundant and easily found in late summer in field plantings that were severely diseased (e.g., $>50 \%$ of the leaves bear one or more mildew colonies).

\section{LITERATURE CITED}

1. Arthur, J. C. 1886. Pages 259-296 in: Report of the Botanist of the New York Experiment Station.

2. Bidwell, R. G. S. 1974. Plant Physiology. Macmillan Publishing Co., New York

3. Blumer, S 1967. Echte Mehltaupilze (Erysiphaceae). Gustav Fischer, Jena.

4. Gadoury, D. M., and Pearson, R. C. 1988. Initiation, development, dispersal, and survival of cleistothecia of Uncinula necator in New York vineyards. Phytopathology 78:1413-1421.
5. Gadoury, D. M., and Pearson, R. C. 1990. Ascocarp dehiscence and ascospore discharge in Uncinula necator. Phytopathology 80:393-401.

6. Gadoury, D. M., and Pearson, R. C. 1991. Heterothallism and pathogenic specialization in Uncinula necator. Phytopathology 81:1287-1293.

7. Gadoury, D. M., Stensvand, A., Seem, R. C., and Heidenreich, C. 2007. Ontogenic resistance of leaves, leaf folding and the distribution of mildew colonies in strawberry powdery mildew (Podosphaera macularis). (Abstr.) Phytopathology 97:S38.

8. Gadoury, D. M., Stensvand, A., Seem, R. C., Heidenreich, C., Herrero, M. L., and Welser, M. 2007. Overwinter survival of cleistothecia, ascospore release, and infection of strawberry by Podosphaera macularis in New York and Norway. (Abstr.) Phytopathology 97:S38.

9. Giles, G. 1961. Contribution á 1' étude de Sphareotheca humuli (DC) Burr. sur fraisiers: biologie et lutte. XII Symp. Phytopharma. Ghent.

10. Howard, C. M., and Albregts, E. E. 1982. Cleistothecia of Sphaerotheca macularis on strawberry plants in Florida. Plant Dis. 66:261-262.

11. Jhooty, J. S., and McKeen, W. E. 1962. The perfect stage of Sphaerotheca macularis on strawberry plants. Phytopathology 55:281-285.

12. Johansen, D. A. 1940. Plant Microtechnique. McGraw-Hill Book Co., New York.

13. Kaluzhny, Y. V., and Zibtsev, V. M. 1992. The biology of strawberry mildew in Ukraine. Mikol. Fitopatol. 26:49-56.

14. Khan, M. L. 1960. The perithecial stage of Sphaerotheca humuli on strawberry. Plant Pathol. 9:18.

15. Maas, J. L. 1998. Compendium of Strawberry Diseases, 2nd ed. American Phytopathological Society, St. Paul, MN.

16. Pearson, R. C., and Gadoury, D. M. 1987. Cleistothecia, the source of primary inoculum for grape powdery mildew in New York. Phytopathology 77:1509-1514.

17. Peries, O. S. 1962. Studies on strawberry mildew, caused by Sphaerotheca macularis (Wallr. ex Fries) Jaczewski. I. Biology of the fungus. Ann. Appl. Biol. 50:211-224.

18. Salmon, E. S. 1900. The strawberry mildew. J. R. Hortic. Soc. 25:132138.

19. Stensvand, A., Herrero, M. L., Gadoury, D. M., and Seem, R. C. 2006. Ascospores as a potential source of spring inoculum for strawberry powdery mildew. Proc. Nordic Assoc. Agric. Sci. 2:21.

20. Weast, R. C., ed. 1968. Handbook of Chemistry and Physics. Chemical Rubber Co., Cleveland. 